\title{
Comparative account of vitamin $C$ contents, antioxidant properties and iron contents of minor fruits in Sri Lanka
}

\author{
Hashini Imalsha Abeysuriya ${ }^{1}$, Vajira P. Bulugahapitiya ${ }^{1^{*}}$ \& Loku Pulukkuttige Jayatissa ${ }^{2}$ \\ ${ }^{1}$ Department of Chemistry, University of Ruhuna, Matara 81000, Sri Lanka \\ ${ }^{2}$ Department of Botany, University of Ruhuna, Matara 81000, Sri Lanka \\ *Email: vajira@chem.ruh.ac.lk
}

\section{ARTICLE HISTORY}

Received: 22 May 2021

Accepted: 08 July 2021

Available online: 19 August 2021

\section{KEYWORDS}

Antioxidant properties

Health factors

Nutritional properties

Sri Lankan fruits

Underutilized fruits

Vitamin C

\section{ABSTRACT}

Sri Lanka is a habitat of diverse fruit varieties; nevertheless $95 \%$ of them are underutilized by people due to unawareness of their nutritional values and health aspects, and hence become 'minor fruits'. This study was aimed on revealing vitamin C, iron and antioxidant contents of 29 varieties of minor fruits (MFs) with the comparison of the same with three best commonly consumable fruits (CFs), namely Carica papaya, Mangifera indica and Psidium guajava. Ascorbic acid (Asc), dehydroascorbic acid (DAsc), vitamin C (TC), phenolic (TP), flavonoid (TF), iron (Fe) contents and antioxidant capacities (AOCs) of fruits were determined using standard methods. The results of mean Asc, DAsc, TC, TP, TF and Fe contents in $100 \mathrm{gm}$ of MFs ranged from 3.1 to $121.5 \mathrm{mg}, 1.2$ to $70.7 \mathrm{mg}, 6.6$ to $136.1 \mathrm{mg}, 24.9$ to $1613.3 \mathrm{mg}$ Gallic acid equivalent, 6.2 to $228.0 \mathrm{mg}$ Quercetin equivalents and 0.2 to $4.9 \mathrm{mg}$ respectively. DPPH and Ferric Reducing Antioxidant Power (FRAP) assays were used for AOCs and variation of $\mathrm{IC}_{50}$ values in a DPPH assay was 1.2 to $245.4 \mathrm{mg} / \mathrm{ml}$ whereas FRAP values ranged from 9.6 to $486.7 \mu \mathrm{mol} \mathrm{FeSO} / \mathrm{gm}$. Among the studied minor fruits, Melastoma malabathricum (Maha bovitiya/ Malabar melastome) is found as the best respect to all considered parameters. As a conclusion, it can be stated that, the Sri Lankan minor fruits are good alternatives to the common fruits as they are recognized as good source of vitamin C, iron and higher content of antioxidants. As an outcome, Sri Lankan minor fruits can be promoted as alternatives to common fruits and as source of revenue for national economy.

\section{Introduction}

Sri Lanka is a land which has been gifted with extremely high biodiversity and hence it is recognized as one of the biodiversity hotspots in the world (1-3). Even though Sri Lanka has been gifted with huge diversity of fruits by the nature, people in the country cultivate and consume only a limited number of fruit species (4). This may be due to the less awareness of nutritional and healthcare properties of them due to lacking data on scientific aspects.

The fruits grown can be divided in to two categories based on the consumer preference as 'mainstream fruits' or 'common fruits' and 'underutilized fruits or minor fruits'. The 'common fruits' are well known and highly palatable and are having a higher demand in the market. In contrast, underutilized fruits are relatively less palatable and hence these are having a lower demand in the market. Some of the underutilized fruit are cultivated in homesteads and hence 'Underutilized domesticated' while the rest of the underutilized fruits which are naturally growing in forests and un-attended areas are considered as minor fruits (5).

In Sri Lanka, $100 \%$ of mainstream fruits are exotic, while more than $50 \%$ of minor fruits are indigenous to Sri Lanka. Most of edible fruits in Sri Lanka remained underutilized or unknown even without knowing taste or nutritional values (6-8). However, these are mainly minor fruits and wasted without utilizing and without knowing the values or potentials (9).

Some studies on underutilized fruits for their antioxidant capacity are highlighted by several authors (10-18). Recently, we have reported a comparative study on total vitamin C contents, antioxidants capacities and iron content of some underutilized fruits, with commonly consumed fruits (19). However, no adequate scientific reports are available on Sri Lankan minor fruits for their nutritional and biochemical properties especially on iron content, total vitamin C, dehydroascorbic acid

(c) Abeysuriya et al. (2021). This is an open-access article distributed under the terms of the Creative Commons Attribution License, which permits unrestricted use, distribution and reproduction in any medium, provided the original author and source are credited (https://creativecommons.org/licenses/by/4.0/). 
contents and antioxidant capacities. The consumption of minor fruits in Sri Lanka has long history but it has been gradually neglected with the advancement of civilization. There is a substantial gap between demand and supply of fruits in the market as rejection of common fruits by general public is more common due to application of toxic chemicals at the various stages of cultivation and storing, aiming profits.

Therefore, the main objective of this research was to promote minor fruits available in Sri Lanka as the best alternative to the common fruits and to promote them as agricultural crops. For this purpose, some important health and nutritional parameters namely, ascorbic acid (Asc), total vitamin C (TC), dehydroascorbic acid (DAsc), total phenol (TP), total flavonoid (TF) and iron (Fe) contents and antioxidant activities (AOCs) of 29 species of minor fruits available in Sri Lanka were determined and compared them with the best three commonly consumed fruits (Carica papaya, Mangifera indica and Psidium guajava).

\section{Materials and Methods}

\section{Fruit samples}

About 29 locally grown Minor fruits (MFs) were used in this study (Table 1). For comparison of the selected parameters, three Common fruits (CFs) were used which were chosen based on our previous study (19). Carica papaya, Mangifera indica and Psidium guajava were selected as the top three CFs. The studied minor fruits were harvested freshly from naturally grown trees at the wild. When fruits are consumed in both ripe and unripe stages at their maturity, both stages were tested (for example, fruits of $L$. camara, $M$. alba etc.). The plants were authenticated with the help of taxonomist, University of Ruhuna, Sri Lanka.

\section{Preparation of fruit samples}

Representative samples were obtained from different plants of the same species. The harvested fruits were combined to obtain the studied sample. A known weight of edible portion, obtained from the sorted and cleaned fruits, was used to prepare extracts. Extractions were done in triplicate.

Table 1. Harvesting season/time of the studied fruit species

\begin{tabular}{|c|c|c|c|c|c|}
\hline $\begin{array}{l}\text { Sl. } \\
\text { No. }\end{array}$ & Botanical name & Common/ Local name(s) & $\begin{array}{l}\text { Edible } \\
\text { part(s) }^{\mathrm{a}}\end{array}$ & $\begin{array}{l}\text { Harvested } \\
\text { location }\end{array}$ & $\begin{array}{l}\text { Harvested } \\
\text { season } \\
\text { Month/year }\end{array}$ \\
\hline & Commonly consumed fruits (CFs) & & & & \\
\hline 1 & Carica papaya $\mathrm{L}$. & Papaya ('Red lady’) & FWPS & $\mathrm{M}^{\mathrm{b}}, \mathrm{SP}^{\mathrm{c}}$ & $03 / 2018$ \\
\hline 2 & Mangifera indica $\mathrm{L}$. & Mango & FWPS & M, SP & $05 / 2017$ \\
\hline \multirow[t]{2}{*}{3} & Psidium guajava $\mathrm{L}$. & Guava (white flesh) & WF & $\mathrm{HB}, \mathrm{SP}$ & $06 / 2017$ \\
\hline & Minor fruits (MFs) & & & & \\
\hline 1 & Acronychia pedunculata (L.) Miq. & Unkenda, Indian aspen & FWS & $\mathrm{RP}$ & $10 / 2017$ \\
\hline 2 & Antidesma alexiteria $\mathrm{L}$. & Heen ambilla, Wild cherry / Ceylon bignay & WF & $\mathrm{RP}$ & $10 / 2017$ \\
\hline 3 & Ardisia willisii Mez. & Lunu dan & FWS & $\mathrm{M}$ & $07 / 2018$ \\
\hline 4 & Artocarpus nobilis Thwaites & Bedi del/ Wal del, Ceylon wild bread fruit & FWPS & $\mathrm{M}$ & $07 / 2018$ \\
\hline 5 & Borassus flabellifer L. & Thal, Palmyrah & FWPS & AN & $01 / 2018$ \\
\hline 6 & Clidemia hirta (L.) D. Don & Kinithulu bovitiya, Soap bush & WF & $\mathrm{M}$ & $08 / 2017$ \\
\hline 7 & Dillenia retusa & Godapara & FWPS & $\mathrm{M}$ & $06 / 2018$ \\
\hline 8 & Dovyalis hebecarpa (Gardner) Warb. & Ketambilla, Ceylon gooseberry & FWPS & M & $10 / 2017$ \\
\hline 9 & Erythroxylum moonii Hochr. & Batakirilla & WF & $\mathrm{M}$ & $09 / 2017$ \\
\hline 10 & Flacourtia indica (Burm.f.) Merr. & Uguressa, Governor's plum & FWS & $\mathrm{M}$ & $06 / 2018$ \\
\hline 11 & Garcinia quaestia Pierre & Rath goraka, Malabar tamarind/ Brindle berry & FWPS & $\mathrm{M}$ & $06 / 2018$ \\
\hline 12 & Garcinia zeylanica Roxb. & Ela goraka, Malabar tamarind/ Brindle berry & FWPS & $\mathrm{M}$ & $07 / 2018$ \\
\hline 13 & Ixora coccinea $\mathrm{L}$. & Rathambala/ Rathmal, Jungle geranium/ Jungle flame & WF & $\mathrm{M}$ & $10 / 2017$ \\
\hline 14 & Lantana camara L. & Gandapana/ Rata hinguru (unripe) & WF & $\mathrm{M}$ & $09 / 2017$ \\
\hline 15 & Lantana camara L. & Gandapana/ Rata hinguru (ripe) & WF & $\mathrm{M}$ & $09 / 2017$ \\
\hline 16 & Melastoma malabathricum $\mathrm{L}$. & $\begin{array}{l}\text { Maha bovitiya/ Katakaluwa, Malabar melastome/ } \\
\text { Indiana rhododendron }\end{array}$ & FWP & M & $10 / 2017$ \\
\hline 17 & Microcos paniculata $\mathrm{L}$. & Kohukirilla, Shiral/ Mahang & FWS & $\mathrm{AN}$ & $07 / 2017$ \\
\hline 18 & Morus alba L. & Rata embilla, Mulberry (unripe) & WF & $\mathrm{M}$ & $09 / 2017$ \\
\hline 19 & Morus alba L. & Rata embilla, Mulberry (ripe) & WF & $\mathrm{M}$ & $09 / 2017$ \\
\hline 20 & Mukia maderaspatana $\mathrm{L}$. & Gonkakiri, Madras pea pumpkin & WF & $\mathrm{M}$ & $10 / 2017$ \\
\hline 21 & Muntingia calabura L. & Jam, Jamaica cherry & WF & $\mathrm{M}$ & $09 / 2017$ \\
\hline 22 & Opuntia dillenii (Ker. Gawl.) Haw. & Pathok, Common prickly pear & FWPS & HB & $09 / 2017$ \\
\hline 23 & Oxalis berrelieri $\mathrm{L}$. & Heen bilin, Lavender sorrel & WF & $\mathrm{M}$ & $09 / 2017$ \\
\hline 24 & Passiflora foetida $\mathrm{L}$. & Del batu, Wild water melon/ Love-in-a-mist & FWP & $\mathrm{M}$ & $09 / 2018$ \\
\hline 25 & Polyalthia korintii (Dunal) Thwaites & Ulkenda & WF & $\mathrm{RP}$ & $10 / 2017$ \\
\hline 26 & Psidium guajava $\mathrm{L}$. & Ambul pera, Wild guava & WF & $\mathrm{M}$ & $09 / 2017$ \\
\hline 27 & Schleichera oleosa (Lour.) Oken & Katu koan, Ceylon oak & FWPS & AN & $08 / 2017$ \\
\hline 28 & Solanum americanum Mill. & Kalu kemberiya, Amarican night shed & WF & $\mathrm{M}$ & $10 / 2017$ \\
\hline 29 & Solanum capsicoides All. & Nai batu/ Dehel batu, Soda apple/ Cockroach berry & FWS & $\mathrm{RP}$ & $08 / 2017$ \\
\hline 30 & Syzygium cumini (L.) Skeels. & Madan, Java-plum/ jamun/ jambolan & FWS & $\mathrm{M}$ & $06 / 2018$ \\
\hline 31 & Trichopus zeylanicus Gaertn. & Bin pol & WF & $\mathrm{M}$ & $06 / 2018$ \\
\hline
\end{tabular}

${ }^{a}$ Edible part(s) of the fruit studied: FWPS - Only flesh without peel and seed(s); FWP - Flesh without peel; FWS - Whole fruit without seed(s);

WF - Whole fruit

${ }^{b}$ Fruits harvested district in Sri Lanka: AN - Anuradhapura; M - Matara; HB - Hambantota; RP - Ratnapura 


\section{Extraction of Vitamin C}

From the ground fruit sample, vitamin C was extracted to the solution containing meta-phosphoric acid and glacial acetic acid (20).

\section{Methanolic extract of fruits}

Maceration was done with methanol to obtain methanolic extract of fruits (21).

\section{Sample analysis}

\section{Quantification of total vitamin C (TC)}

Quantification of Vitamin C was done using a method with slight modification (22). Briefly, bromine water was added into extract to oxidize all Asc to DAsc and then excess of bromine was removed by adding of thiourea solution. After adding 2,4dinitrophenylhydrazine solution, all samples, standards and blanks were kept in a water bath (37 ${ }^{\circ} \mathrm{C}$ ) for $3 \mathrm{hrs}$ and the absorbance was measured at 520 $\mathrm{nm}$, after addition of sulfuric acid $(85 \%, \mathrm{v} / \mathrm{v})$ to each sample.

\section{Quantification of ascorbic acid (Asc)}

Asc of fruits samples were determined using two methods. At the first method, quantification of Asc was done by titrating with iodine (23).

The AOAC's official titrimetric method for the determination of Asc as explained was used as the second method (20). Each titration was triplicated.

Iodine titrimetric method was applied with to all fruits while 2,6-dichlorophenolindophenol titrimetric method was not possible to intense colored fruits extracts (M. malabathricum, $C$. hirta, S. americanum, S. cumini, O. dillenii, $I$. coccinea, D. retusa, M. alba (ripe), G. quaestia, G. zeylanica and T. zeylanicus).

\section{Quantification of dehydroascorbic acid (DAsc)}

DAsc content of the fruits was obtained using following equation:

Dehydroascorbic acid content $=$

[Total vitamin C content] - [Mean Ascorbic acid content].

\section{Quantification of total phenolic (TP)}

Folin-Ciocalteu's reagent $(2.5 \mathrm{ml})$ was mixed with fruit extract $(0.5 \mathrm{ml})$. After $5 \mathrm{~min}, \mathrm{Na} 2 \mathrm{CO} 3(2 \mathrm{ml}$ of $7.5 \% \mathrm{w} / \mathrm{v}$ ) was added and the absorbance was measured at $765 \mathrm{~nm}$ after incubating in the dark for $30 \mathrm{~min}$. Total phenol content was quantified using a standard curve of gallic acid $(0.02-0.1 \mathrm{mg} / \mathrm{ml})$ and TP contents of fruits were expressed in $\mathrm{mg}$ of gallic acid equivalents (GE) per $100 \mathrm{gm}$ of fresh fruit (24).

\section{Quantification of total flavonoid (TF)}

A mixture containing fruits extract $(1 \mathrm{ml})$, methanol ( $3 \mathrm{ml}), 10 \%$ (w/v) Aluminium chloride solution $(0.2$ $\mathrm{ml}), 1 \mathrm{M}$ potassium acetate $(0.2 \mathrm{ml})$ and distilled water $(5.6 \mathrm{ml})$ was used, the absorbance was measured at $420 \mathrm{~nm}$ after incubating in the dark for $30 \mathrm{~min}$. TF of each fruit extract was determined using a standard curve prepared with Quercetin (0.01-0.1 $\mathrm{mg} / \mathrm{ml}$ ). TF contents of fruits were expressed as $\mathrm{mg}$ of Quercetin equivalents (QE) per 100 gm of fresh fruit (25).

\section{DPPH assay}

Fruit extracts (100 $\mu \mathrm{l})$ with 6 different concentrations were mixed with $3.9 \mathrm{ml}$ of methonolic DPPH radical solution $(0.06 \mathrm{mM})$ and samples were stand in the dark for $30 \mathrm{~min}$ and absorbance (at $517 \mathrm{~nm}$ ) was measured. The antioxidant activity was expressed by $\mathrm{IC}_{50}$ value that was calculated using the plot of $\%$ disappearance vs. concentration (here concentration is $\mathrm{mg}$ of fruit extract into $1 \mathrm{ml}$ of solution) (26).

\section{FRAP assay}

Properly diluted sample $(100 \mu \mathrm{l})$ was mixed with FRAP reagent $(3 \mathrm{ml})$ and absorbance was measured at $593 \mathrm{~nm}$, after incubating at $37^{\circ} \mathrm{C}$ for $30 \mathrm{~min}$. Aqueous solutions of $\mathrm{FeSO}_{4} \cdot 7 \mathrm{H}_{2} \mathrm{O}$ with the concentration ranged from 100 to $1200 \mathrm{mM}$ were used for calibration (27).

\section{Quantification of total iron (Fe)}

The fruit $(10-20 \mathrm{gm})$ was burnt in a muffle furnace (Yamato FM-36) (at $450{ }^{\circ} \mathrm{C}$ ) to get white/ gray colour ash and the residue in the crucible was dried on a hot plate after adding $6 \mathrm{M} \mathrm{HCl}(5 \mathrm{ml})$ and remaining content was dissolved in $0.1 \mathrm{M} \mathrm{HNO}_{3}(15 \mathrm{ml})(28)$. The dissolved content was transferred and the volume was made to $25 \mathrm{ml}$ with $0.1 \mathrm{M} \mathrm{HNO}_{3}$. The above ample was mixed with Conc. $\mathrm{H}_{2} \mathrm{SO}_{4}(0.5 \mathrm{ml})$, saturated $\mathrm{K}_{2} \mathrm{~S}_{2} \mathrm{O}_{8}(1 \mathrm{ml})$ and $3 \mathrm{~N} \mathrm{KSCN}(2 \mathrm{ml})$ and volume was made up to $15 \mathrm{ml}$. Absorbance was measured immediately at $480 \mathrm{~nm}$. Calibration curve was built using iron standards ranged from 5 to $25 \mathrm{mg} / \mathrm{l}$ (22).

\section{Statistical analysis}

One-way analysis of variance (ANOVA) and Tukey post-hoc test was used to find out the significant differences $(p<0.05)$ of the means $(\mathrm{n}=3)$ of studied parameters of fruits. Dependent variables are TC, mean Asc, DAsc, TP, TF, antiradical power (ARP), FRAP value and Fe content. Statistical analysis was carried out using the IBM SPSS 25.0 package (SPSS Inc., Chicago, USA). Classification and discrimination between fruits were done by PCA. In PCA, DPPH assay data were fed as ARP $\left(\mathrm{ARP}=1 / \mathrm{IC}_{50}\right)$.

\section{Results and Discussion}

\section{Comparison of total vitamin $C(T C)$, ascorbic acid (Asc) and dehydroascorbic acid (DAsc) contents of underutilized minor fruits (MFs)}

TC, Asc and DAsc contents of MFs in Sri Lanka is given in Table 2 and it varies from 6.6 to 136.1 $\mathrm{mg} / 100 \mathrm{gm}$ FW (Fresh weight), while $A$. willisii being the fruit with highest TC followed by M. calabura and $M$. malabathricum. Only these three fruits are the fruits with high TC content and $C$. hirta, D. hebecarpa and $S$. americanum are the fruits with moderately high TC among studied MFs. The lowest TC was observed in $F$. indica. Mean Asc content was in the range of $3.1-121.5 \mathrm{mg} / 100 \mathrm{gm} \mathrm{FW}$ in MFs. $M$. calabura followed by $M$. malabathricum and $C$. hirta are the fruits with highest Asc content. These three MF species contain Asc greater than $100 \mathrm{mg} / 100 \mathrm{gm}$ FW but any of the common fruits do not contain Asc larger than $100 \mathrm{mg} / 100 \mathrm{gm}$ FW. 
This study emphasizes higher Asc and TC contents in MFs compared to CFs with minor exceptions such as wild guava which has significantly lower Asc content compared to cultivated guava ' $c v$. Horana white' (18). DAsc content of MFs varied between 1.2 to $70.7 \mathrm{mg} / 100 \mathrm{gm}$ FW (Table 2). The highest DAsc content was observed in A. willisii while decrease as they ripen and then remains at a fairly stable level until complete ripening. On considering the acidity and sugar levels of fruits, it has been reported that, acidity decreases while sugar content increases (30). Consequently, this changes the redox state of the fruit and the activity of enzymes related to ascorbate metabolism. In addition, the breakdown

Table 2. TC, Asc, DAsc and iron content of minor fruits, compared to selected CFs in Sri Lanka

\begin{tabular}{|c|c|c|c|c|c|}
\hline Fruits & $\begin{array}{c}\text { TC } \\
(\mathrm{mg} / 100 \mathrm{gm} \text { FW) }\end{array}$ & $\begin{array}{c}\text { Asc- } \text { I }_{2} \\
\text { (mg AscE/ } 100 \mathrm{gm} \\
\text { FW) }\end{array}$ & $\begin{array}{l}\text { Asc-DCPIP (mg } \\
\text { AscE/ } 100 \text { gm FW) }\end{array}$ & $\begin{array}{l}\text { DAsc (mg/ } \\
100 \text { gm FW) }\end{array}$ & $\begin{array}{c}\text { Fe content } \\
(\mathrm{mg} \text { of Fe(III)/ } \\
100 \mathrm{gm} \text { FW) }\end{array}$ \\
\hline \multicolumn{6}{|c|}{ Commonly consumed fruits (CFs) } \\
\hline C. papaya & $73.2 \pm 1.6^{\mathrm{b}}$ & $69.5 \pm 1.7^{\mathrm{b}}$ & $64.9 \pm 1.8^{\mathrm{b}}$ & 6.0 & $0.3 \pm 0.0$ \\
\hline M. indica & $36.8 \pm 0.4^{\mathrm{a}}$ & $30.8 \pm 0.4^{\mathrm{a}}$ & $28.8 \pm 0.2^{\mathrm{a}}$ & 7.1 & $0.2 \pm 0.1$ \\
\hline P. guajava (white flesh) & $76.2 \pm 0.7^{c}$ & $68.8 \pm 1.0^{\mathrm{b}}$ & $70.3 \pm 0.3^{c}$ & 6.7 & $1.1 \pm 0.1$ \\
\hline \multicolumn{6}{|l|}{ Minor fruits (MFs) } \\
\hline A. alexiteria & $46.1 \pm 0.3^{\text {no }}$ & $30.3 \pm 0.5^{n}$ & $28.7 \pm 1.2^{\mathrm{k}}$ & 16.6 & $0.4 \pm 0.1$ \\
\hline A. nobilis & $14.3 \pm 2.6^{\mathrm{de}}$ & $4.6 \pm 0.4^{\mathrm{b}}$ & $4.0 \pm 0.6^{\mathrm{b}}$ & 10.0 & $0.4 \pm 0.1$ \\
\hline A. pedunculata & $24.8 \pm 1.0^{\mathrm{ij}}$ & $18.9 \pm 1.0^{\text {fghi }}$ & $17.0 \pm 0.7^{\mathrm{fgh}}$ & 5.9 & $1.3 \pm 0.1$ \\
\hline A. willisii & $136.1 \pm 5.4^{\mathrm{r}}$ & $67.4 \pm 1.8^{\mathrm{p}}$ & $63.4 \pm 3.5^{1}$ & 70.7 & $0.4 \pm 0.1$ \\
\hline B. flabellifer & $20.4 \pm 1.2^{\text {ghi }}$ & $8.1 \pm 0.4^{\mathrm{c}}$ & $7.2 \pm 0.3^{\mathrm{c}}$ & 12.8 & $0.2 \pm 0.0$ \\
\hline C. hirta & $75.8 \pm 0.3^{\mathrm{p}}$ & $68.9 \pm 1.0^{\mathrm{p}}$ & NA & 6.9 & $0.3 \pm 0.1$ \\
\hline D. hebecarpa & $70.9 \pm 0.3^{p}$ & $66.8 \pm 3.8^{p}$ & $68.9 \pm 0.5^{1}$ & 3.0 & $0.2 \pm 0.0$ \\
\hline D. retusa & $18.0 \pm 1.8^{\mathrm{fg}}$ & $10.9 \pm 0.4^{\mathrm{d}}$ & NA & 7.1 & $0.3 \pm 0.1$ \\
\hline E. moonii & $20.3 \pm 0.3^{\text {ghi }}$ & $18.1 \pm 0.7^{\mathrm{fgh}}$ & $14.4 \pm 0.9^{\mathrm{ef}}$ & 4.1 & $0.3 \pm 0.1$ \\
\hline F. indica & $6.6 \pm 0.4^{\mathrm{a}}$ & $3.3 \pm 0.5^{\mathrm{a}}$ & $2.9 \pm 0.3^{\mathrm{a}}$ & 3.5 & $0.4 \pm 0.1$ \\
\hline G. quaestia & $12.8 \pm 0.5^{\text {cd }}$ & $11.0 \pm 0.7^{\mathrm{d}}$ & NA & 1.8 & $0.5 \pm 0.2$ \\
\hline G. zeylanica & $11.4 \pm 0.8^{\mathrm{bc}}$ & $7.7 \pm 0.9^{c}$ & NA & 3.7 & $0.3 \pm 0.0$ \\
\hline I. coccinea & $29.8 \pm 0.2^{\mathrm{jk}}$ & $23.9 \pm 0.4^{j \mathrm{klm}}$ & NA & 5.9 & $0.3 \pm 0.1$ \\
\hline L. camara (unripe) & $28.6 \pm 0.2^{\mathrm{jk}}$ & $22.9 \pm 0.3^{\mathrm{ijklm}}$ & $19.5 \pm 0.6 h^{\mathrm{i}}$ & 7.4 & $0.6 \pm 0.1$ \\
\hline L. camara (ripe) & $37.3 \pm 0.3^{\operatorname{lmn}}$ & $21.0 \pm 0.6^{\text {hijkl }}$ & $19.1 \pm 0.8^{\mathrm{hi}}$ & 17.2 & $0.6 \pm 0.1$ \\
\hline M. alba (unripe) & $18.6 \pm 0.6^{\mathrm{fgh}}$ & $15.3 \pm 0.2^{\mathrm{ef}}$ & $13.6 \pm 0.7^{\mathrm{e}}$ & 4.2 & $1.4 \pm 0.1$ \\
\hline M. alba (ripe) & $17.9 \pm 0.2^{\mathrm{fg}}$ & $16.7 \pm 0.4^{\mathrm{fg}}$ & NA & 1.2 & $1.4 \pm 0.1$ \\
\hline M. calabura & $123.7 \pm 0.4^{\mathrm{q}}$ & $121.7 \pm 2.7^{\mathrm{r}}$ & $121.2 \pm 1.6^{\mathrm{m}}$ & 2.2 & $0.4 \pm 0.1$ \\
\hline M. maderaspatana & $21.9 \pm 1.8^{\text {ghi }}$ & $19.7 \pm 0.9^{\text {ghij }}$ & $18.3 \pm 1.3^{\mathrm{gh}}$ & 2.9 & $0.4 \pm 0.1$ \\
\hline M. malabathricum & $101.6 \pm 1.0^{\mathrm{q}}$ & $95.3 \pm 0.8^{q}$ & NA & 6.3 & $0.3 \pm 0.1$ \\
\hline M. paniculata & $21.6 \pm 0.3^{\text {ghi }}$ & $20.2 \pm 0.2^{\text {ghijk }}$ & $18.8 \pm 0.8^{\mathrm{h}}$ & 2.1 & $0.6 \pm 0.1$ \\
\hline O. berrelieri & $30.8 \pm 0.1^{\mathrm{kl}}$ & $25.1 \pm 0.3^{\operatorname{lmn}}$ & $24.1 \pm 1.6^{j}$ & 6.2 & $0.3 \pm 0.1$ \\
\hline O. dillenii & $30.4 \pm 0.4^{\mathrm{jkl}}$ & $24.3 \pm 0.5^{\mathrm{klm}}$ & NA & 18.2 & $0.4 \pm 0.1$ \\
\hline P. foetida & $22.4 \pm 0.9^{\mathrm{hi}}$ & $12.9 \pm 0.9^{\mathrm{de}}$ & $10.6 \pm 0.7^{\mathrm{d}}$ & 10.7 & $1.0 \pm 0.3$ \\
\hline P. guajava (wild) & $39.7 \pm 0.3^{\mathrm{mn}}$ & $17.1 \pm 1.0^{\mathrm{fgh}}$ & $15.5 \pm 0.8^{\mathrm{efg}}$ & 23.4 & $0.6 \pm 0.1$ \\
\hline P. korintii & $15.9 \pm 0.2^{\mathrm{ef}}$ & $12.9 \pm 0.6^{\mathrm{de}}$ & $10.8 \pm 0.7^{\mathrm{d}}$ & 4.1 & $0.4 \pm 0.1$ \\
\hline S. americanum & $52.4 \pm 0.4^{\circ}$ & $42.5 \pm 0.5^{\circ}$ & NA & 9.9 & $1.1 \pm 0.2$ \\
\hline S. capsicoides & $32.0 \pm 0.4^{\mathrm{klm}}$ & $26.0 \pm 0.7^{\mathrm{mn}}$ & $22.4 \pm 0.8^{i j}$ & 7.8 & $0.4 \pm 0.1$ \\
\hline S. cumini & $33.3 \pm 1.9^{\mathrm{klm}}$ & $13.4 \pm 0.5^{\mathrm{de}}$ & NA & 26.6 & $0.4 \pm 0.0$ \\
\hline S. oleosa & $22.7 \pm 1.6^{\mathrm{hi}}$ & $19.6 \pm 2.4^{\text {ghij }}$ & $17.4 \pm 0.7^{\mathrm{gh}}$ & 4.3 & $0.4 \pm 0.1$ \\
\hline T. zeylanicus & $9.9 \pm 2.3^{\mathrm{b}}$ & $7.3 \pm 1.3^{\mathrm{c}}$ & NA & 2.6 & $4.9 \pm 1.1$ \\
\hline
\end{tabular}

Means with different superscript letters in individual column for each fruit category are significantly $(p<0.05)$ different from each other NA - Not applicable; TC - Total vitamin C content, Asc - Ascorbic acid content, DAsc - Dehydroascorbic acid content; Asc-I I $_{2}$ - Ascorbic acid content determined by iodine titrimetric method, Asc-DCPIP - Ascorbic acid content determined by 2,6-dichlorophenolindophenol titrimetric method, AscE - Ascorbic acid equivalent.

lowest was observed in ripe fruits of $M$. alba.

When the two maturity stages of L. camara were considered, it was observed that TC has increased upon ripening of the fruit. Ripe fruits had significantly higher TC compared to unripe stage, but Asc content remained unchanged for two stages. The possible reason could be the rapid conversion of Asc to DAsc during ripening while actively continuing biosynthesis pathway of Asc. In contrast, there was no significant change in Asc and TC contents in $M$. alba during ripening. Asc content in some fruits such as, Solanum lycopersicum, Vitis vinifera, Fragaria spp. etc. increase with the ripening. However, the fruits like Prunus persica and Actinidia spp., a maximum Asc level is achieved at the immature stage and gradually decreased during ripening (29). These fruits must have higher biosynthesis rate initially but of pectin due to degradation of cell wall during ripening may provide more supply of Dgalacturonate, which helps the synthesis of Asc. However, the variation of Asc during ripening of fruit is an attribute dependent on the species (29). Similar Asc content for the MF, $M$. alba, has been reported by Ercisli and Orhan (22.4 mg/100 gm) (31) and Gungor and Sengul (10.5 - $21.50 \mathrm{mg} / 100 \mathrm{gm}$ ) (32).

\section{Comparison of total phenolic (TP), total flavonoid (TF) contents and antioxidant capacities (AOCs) of underutilized minor fruits (MFs)}

As given in Table 3, TP contents of studied MFs greatly varied in between 24.9 to $1613.3 \mathrm{mg}$ GE (Gallic acid equivalent)/100 gm of FW with the highest and the lowest TP content in $M$. malabathricum and $O$. berrelieri respectively. When all the fruits are considered, M. malabathricum contains the highest 
TP content followed by $C$. hirta and $M$. paniculata. From CFs, highest TP and TF contents were observed in P. guajava (white), but its TP content is about 9 times lower than that of $M$. malabathricum. TP content of ripe fruits of $L$. camara and $M$. alba are higher than in unripe stage, emphasizing that significant increase in TP during ripening. Increase in $\mathrm{TP}$ and antioxidant capacities with ripening has been reported by previous researchers for Vaccinium ashei (33) and Solanum lycopersicum (34). In contrast some authors have reported decrease in TP in $P$. guajava (35), Musa spp. (36) and $M$. indica (37) during ripening. TF of minor fruits are ranged from 6.2 to $228.0 \mathrm{mg}$ QE (Quercetin equivalent)/100 gm FW while $M$. malabathricum and $C$. hirta reported to have the highest and they are the only fruits with TF higher than $100 \mathrm{mg}$ QE/100 gm FW. The MF, F. indica is with $\mathrm{mg} / \mathrm{ml}$ giving the highest $\mathrm{AOC}$ (lowest $\mathrm{IC}_{50}$ ) in $M$. malabathricum followed by $A$. willisii, $C$. hirta, $M$. calabura, $A$. pedunculata and $A$. alexiteria. The lowest AOC (highest $\mathrm{IC}_{50}$ ) was observed in $T$. zeylanicus followed by $B$. flabellifer and $G$. zeylanica. MFs have high free radical scavenging capacity compared to CFs. From the CFs, $P$. guajava (white flesh) shows the highest radical scavenging capacity, but about 8 times less than $M$. malabathricum.

\section{FRAP values of minor fruits}

FRAP values of MFs studied is given in Table 3 and they are varied within a wide range of 9.6 to 486.7 $\mu \mathrm{mol} \mathrm{FeSO}_{4} / \mathrm{gm} \mathrm{FW}$ while $M$. malabathricum showed the highest FRAP (highest AOC) followed by A. willisii, C. hirta and M. calabura. The lowest AOC in FRAP was observed in G. zeylanica. Among CFs the highest

Table 3. TP and TF contents of minor underutilized fruits, compared to selected CFs in Sri Lanka

\begin{tabular}{|c|c|c|c|c|}
\hline Fruits & $\begin{array}{c}\text { TP } \\
(\mathrm{mg} \mathrm{GE} / 100 \mathrm{gm} \text { FW) }\end{array}$ & $\begin{array}{c}\text { TF } \\
\text { (mg QE/100 gm FW) }\end{array}$ & $\begin{array}{c}\mathrm{DPPH}-\mathrm{IC}_{50} \\
(\mathrm{mg} / \mathrm{ml})\end{array}$ & 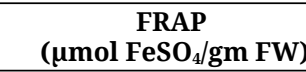 \\
\hline \multicolumn{5}{|c|}{ Commonly consumed fruits (CFs) } \\
\hline C. papaya & $57.4 \pm 1.1^{\mathrm{a}}$ & $17.3 \pm 0.4^{\mathrm{a}}$ & $120.0 \pm 10.0^{b}$ & $108.3 \pm 7.6^{\mathrm{a}}$ \\
\hline M. indica & $103.8 \pm 15.4^{b}$ & $62.2 \pm 2.8^{b}$ & $12.9 \pm 2.1^{\mathrm{a}}$ & $950.0 \pm 78.1^{b}$ \\
\hline P. guajava (white flesh) & $180.6 \pm 4.3^{\mathrm{c}}$ & $92.0 \pm 0.3^{\mathrm{c}}$ & $9.8 \pm 0.1^{\mathrm{a}}$ & $131.5 \pm 0.5^{\mathrm{a}}$ \\
\hline \multicolumn{5}{|l|}{ Minor fruits (MFs) } \\
\hline A. alexiteria & $580.6 \pm 65.1^{\text {nop }}$ & $35.3 \pm 4.6^{\text {hij }}$ & $5.0 \pm 1.0^{\mathrm{lm}}$ & $152.7 \pm 9.3^{p}$ \\
\hline A. nobilis & $89.7 \pm 11.5^{\text {def }}$ & $44.0 \pm 1.0^{\mathrm{ijkl}}$ & $69.1 \pm 5.2^{\text {cd }}$ & $12.3 \pm 2.5^{\mathrm{ab}}$ \\
\hline A. pedunculata & $493.3 \pm 95.0^{\operatorname{lmno}}$ & $57.3 \pm 2.4^{\operatorname{lmno}}$ & $4.4 \pm 0.4^{\mathrm{m}}$ & $115.0 \pm 15.0^{\text {nop }}$ \\
\hline A. willisii & $716.0 \pm 121.8^{\text {op }}$ & $66.0 \pm 3.6^{\text {mnop }}$ & $1.3 \pm 0.2^{\circ}$ & $330.0 \pm 26.5^{q}$ \\
\hline B. flabellifer & $41.2 \pm 9.3^{\mathrm{abc}}$ & $17.8 \pm 1.9^{\mathrm{de}}$ & $228.7 \pm 28.0^{\mathrm{a}}$ & $27.3 \pm 2.5^{\mathrm{de}}$ \\
\hline C. hirta & $974.3 \pm 31.0^{p}$ & $181.7 \pm 23.6^{r}$ & $1.5 \pm 0.5^{\circ}$ & $310.1 \pm 10.0^{q}$ \\
\hline D. hebecarpa & $27.8 \pm 2.6^{\mathrm{ab}}$ & $20.5 \pm 3.9^{\text {ef }}$ & $9.5 \pm 0.5^{\mathrm{k}}$ & $121.7 \pm 7.6^{\text {nop }}$ \\
\hline D. retusa & $122.7 \pm 11.9^{\text {efgh }}$ & $31.0 \pm 5.0^{\text {ghi }}$ & $81.9 \pm 1.9^{\mathrm{bc}}$ & $35.2 \pm 4.8^{\mathrm{efgh}}$ \\
\hline E. moonii & $294.9 \pm 47.2^{\mathrm{jklm}}$ & $55.3 \pm 4.3^{\operatorname{lmno}}$ & $25.2 \pm 0.4^{\mathrm{gh}}$ & $67.3 \pm 2.5^{\mathrm{jkl}}$ \\
\hline F. indica & $112.0 \pm 26.2^{\text {efg }}$ & $6.2 \pm 1.3^{\mathrm{a}}$ & $107.0 \pm 8.0^{\mathrm{b}}$ & $42.7 \pm 2.5^{\text {fghi }}$ \\
\hline G. quaestia & $155.3 \pm 10.3^{\text {fghij }}$ & $52.7 \pm 2.5^{\mathrm{klm}}$ & $53.2 \pm 2.8^{\mathrm{de}}$ & $47.0 \pm 2.6^{\text {ghij }}$ \\
\hline G. zeylanica & $126.4 \pm 8.4^{\text {efgh }}$ & $8.5 \pm 1.3^{\mathrm{ab}}$ & $205.3 \pm 12.9^{\mathrm{a}}$ & $9.6 \pm 0.5^{\mathrm{a}}$ \\
\hline I. coccinea & $270.2 \pm 27.8^{\mathrm{ijkl}}$ & $99.0 \pm 18.2^{q}$ & $11.0 \pm 1.0^{\mathrm{jk}}$ & $77.0 \pm 14.7^{\mathrm{klm}}$ \\
\hline L. camara (unripe) & $93.2 \pm 6.1^{\text {def }}$ & $79.5 \pm 5.2^{\text {opq }}$ & $10.8 \pm 0.3^{\mathrm{k}}$ & $91.9 \pm 12.7^{1 \mathrm{mno}}$ \\
\hline L. camara (ripe) & $330.7 \pm 26.9^{\mathrm{klmn}}$ & $89.0 \pm 10.1^{\mathrm{pq}}$ & $198.3 \pm 12.6^{\mathrm{a}}$ & $32.9 \pm 2.6^{\text {defg }}$ \\
\hline M. alba (unripe) & $97.4 \pm 10.9^{\text {def }}$ & $\mathrm{ND}$ & $96.1 \pm 3.9^{\mathrm{bc}}$ & $18.1 \pm 1.1^{\mathrm{c}}$ \\
\hline M. alba (ripe) & $141.0 \pm 9.9^{\text {fghi }}$ & $33.3 \pm 2.1^{\mathrm{hi}}$ & $50.5 \pm 5.1^{\mathrm{de}}$ & $85.0 \pm 5.0^{\operatorname{lmn}}$ \\
\hline M. calabura & $597.5 \pm 55.7^{\text {nop }}$ & $76.5 \pm 3.1^{\text {nopq }}$ & $2.3 \pm 0.4^{\mathrm{n}}$ & $272.0 \pm 65.8^{q}$ \\
\hline M. maderaspatana & $204.4 \pm 41.9^{\text {ghijk }}$ & $63.6 \pm 1.2^{\mathrm{mnop}}$ & $12.0 \pm 1.0^{\mathrm{jk}}$ & $34.3 \pm 5.1^{\text {efgh }}$ \\
\hline M. malabathricum & $1613.3 \pm 126.6^{q}$ & $228.0 \pm 27.1^{r}$ & $1.2 \pm 0.3^{\circ}$ & $486.7 \pm 15.3^{r}$ \\
\hline M. paniculata & $937.5 \pm 54.5^{\mathrm{op}}$ & $36.9 \pm 5.6^{\text {hijk }}$ & $68.4 \pm 2.9^{\text {cd }}$ & $34.1 \pm 5.1^{\mathrm{efg}}$ \\
\hline O. berrelieri & $24.9 \pm 5.0^{\mathrm{a}}$ & $16.8 \pm 2.8^{\text {cde }}$ & $15.4 \pm 1.0^{\mathrm{ij}}$ & $101.8 \pm 16.0^{\mathrm{mno}}$ \\
\hline O. dillenii & $128.0 \pm 24.4^{\text {efgh }}$ & $12.0 \pm 1.8^{\mathrm{bc}}$ & NA & $34.1 \pm 3.3^{\mathrm{efg}}$ \\
\hline P. foetida & $91.5 \pm 10.6^{\text {def }}$ & $26.0 \pm 4.0^{\mathrm{fgh}}$ & $86.8 \pm 2.8^{\mathrm{bc}}$ & $17.0 \pm 2.6^{\mathrm{bc}}$ \\
\hline P. guajava (wild) & $227.8 \pm 59.2^{\text {hijk }}$ & $14.0 \pm 1.0^{\mathrm{cd}}$ & $10.4 \pm 0.5^{\mathrm{k}}$ & $75.2 \pm 4.2^{\mathrm{klm}}$ \\
\hline P. korintii & $52.3 \pm 3.1^{\text {bcd }}$ & $16.9 \pm 1.6^{\text {cde }}$ & $76.4 \pm 5.1^{\mathrm{bc}}$ & $31.2 \pm 2.3^{\text {def }}$ \\
\hline S. americanum & $536.7 \pm 32.1^{\mathrm{mnop}}$ & $51.2 \pm 1.1^{\mathrm{klm}}$ & $40.8 \pm 0.9^{\mathrm{ef}}$ & $53.7 \pm 5.5^{\mathrm{ijk}}$ \\
\hline S. capsicoides & $207.1 \pm 32.9^{\text {ghijk }}$ & $49.5 \pm 1.7^{\mathrm{jklm}}$ & $43.8 \pm 3.8^{\mathrm{e}}$ & $23.0 \pm 2.1^{\text {cd }}$ \\
\hline S. cumini & $258.2 \pm 20.1^{\mathrm{ijkl}}$ & $53.7 \pm 1.7^{1 \mathrm{mn}}$ & $18.3 \pm 1.8^{\text {hi }}$ & $107.7 \pm 8.1^{\mathrm{mnop}}$ \\
\hline S. oleosa & $213.7 \pm 30.2^{\text {ghijk }}$ & $21.1 \pm 2.1^{\text {ef }}$ & $30.3 \pm 3.0^{\mathrm{fg}}$ & $49.2 \pm 0.7^{\text {hij }}$ \\
\hline T. zeylanicus & $71.3 \pm 18.2^{\text {cde }}$ & $21.7 \pm 1.5^{\mathrm{efg}}$ & $245.4 \pm 13.6^{\mathrm{a}}$ & $12.3 \pm 2.5^{\mathrm{ab}}$ \\
\hline
\end{tabular}

Means with different superscript letters in individual column for each fruit category are significantly ( $p<0.05)$ different from each other.

ND - Not detected; NA - Not applicable; TP - Total phenolic content; TF - Total flavonoid content; GE - Gallic acid equivalents; QE Quercetin equivalent.

the lowest TF. It was reported similar values for TP (181 mg GE/100 gm) and TF (29 mg QE/100 gm) for $M$. alba as obtained in this study (31).

\section{DPPH assays for underutilized minor fruits}

$\mathrm{DPPH}$ assay measures the quenching DPPH radical by concerned extracts, and given as $\mathrm{IC}_{50}$ values (Table 3 ). Accordingly, the $\mathrm{IC}_{50}$ varied in between 1.2 to 245.4
FRAP was observed in $M$. indica and it has a higher FRAP value compared to the MF; M. malabathricum. When both AOC assays are considered, $M$. malabathricum, A. willisii, $C$. hirta and $M$. calabura are the MFs with highest AOCs. M. malabathricum and $C$. hirta are the fruits with highest $\mathrm{TP}$ and $\mathrm{TF}$ contents. The higher TP and TF can be responsible for the high AOCs. Some contradict results has been 
observed for example, high AOC in A. willisii is not due to the high TP and TF, but due to high amount of TC. In D. hebecarpa and $O$. berrelieri, the TP and TF are low whereas TC, Asc and AOCs are high. These results revealed that higher level of AOC in $D$. hebecarpa is due to higher contents of TC and Asc not because of TP and TF. It has been observed that the major contribution of Asc for antioxidant capacity other than phenolic compounds (38).

\section{Iron (Fe) content of minor fruits}

Fe contents of MFs studied are given in Table 2 and it varied in between 4.9 and $0.2 \mathrm{mg} / 100 \mathrm{gm}$ FW. Fe contents were high in the fruit of $T$. zeylanicus and then showed reducing in $M$. alba, A. pedunculata, $S$. americanum and $P$. foetida. However, these fruits contain significantly higher iron contents than the iron content of commonly consumed fruit, $P$. guajava (white flesh).

This study gets credited as the first study done for many important health and nutritional parameters such as Asc, TC, DAsc, TP, TF, Fe contents and AOCs for higher number of MFs. According to our knowledge, only two studies on minor fruits have been reported by Sri Lankan scientists. One is AOC of S. oleosa (9) and the other was AOC of MF, A. alexiteria (39) observation is on similar TP (223.67 mg GE/100 gm) for S. oleosa (9). They also have determined DPPH (1580 ppm) and FRAP value $\left(1.12 \mathrm{Fe}^{2+} \mathrm{mM} / \mathrm{gm}\right)$ of $S$. oleosa. Agreeing with our results (39). It was reported that TP in A. alexiteria that is ranged from 3.33 to 6.77 $\mathrm{mg} \mathrm{GE} / \mathrm{gm}$.

Some literature data on minor fruits considered in this study are available for from other countries as many of those fruits are underutilized in other countries as well. The antioxidant properties of minor fruits, $M$. alba, $S$. cumini and $D$. hebecarpa etc. have been reported by many researchers $(31,32,40-43)$. A similar Asc content for $S$. cumini (14 mg/100 gm) was also reported (41). However, discordant value for Asc of $S$. cumini (112 mg/100 gm) has been observed (42). TP of S. cumini that ranged from 497 to $185 \mathrm{mg}$ GE/100 gm as reported (41) and (42) respectively.

D. hebecarpa is a fruit native to Sri Lanka and it is a good source of anthocyanin (44, 45). According to past studies, vitamin C content of $D$. hebecarpa is ranged from $98 \mathrm{mg} / 100 \mathrm{gm} \mathrm{(44)} \mathrm{to}$ $143.4 \mathrm{mg} / 100 \mathrm{gm}$ (46). TP of $D$. hebecarpa as observed (45) is ranged from 195 to $239 \mathrm{mg} \mathrm{GE} / 100$ gm FW. Same reports are on AOC of $D$. hebecarpa, determined by FRAP assay $10.7-13.8 \mu \mathrm{mol} \mathrm{GE} / \mathrm{gm}$ and $7.9-10.3 \mu \mathrm{mol}$ trolox equivalents (TE)/gm (45). $\mathrm{TP}$ and TF values lower than ours which is $4.35 \mathrm{mg}$ $\mathrm{GE} / 100 \mathrm{gm}$ and $9.64 \mathrm{mg}$ QE/100 gm respectively (46). Furthermore, the authors have reported AOC as DPPH and FRAP for D. hebecarpa as, $17.08 \mathrm{mg}$ $\mathrm{TE} / 100 \mathrm{gm}$ and $487.13 \mathrm{mg} \mathrm{FeSO}_{4} / 100 \mathrm{gm}$ respectively (46). It was reported that $\mathrm{TP}$ and vitamin $C$ contents of $A$. pedunculata as $0.8 \mathrm{gm}$ gallic acid/100 gm dry weight and $6.0 \mu \mathrm{mol}$ ascorbate/g dry weight. Moreover, the author has elaborated that main flavonoids present in $A$. pedunculata are flavanones (naringin), phenolic acids and phenolic terpenoids (47).

As Asc can support the non-heme iron absorption, fruit sources which contain high Asc and iron can help to prevent iron deficiency among people (48). For developing countries like Sri Lanka, MF species will be important as low cost sources to alleviate iron deficiency anemia from the society. S. Americanum and P. guajava (white flesh) can be considered as a potential source of iron as well as Asc that may have iron with high bioavailability. Although T. zeylanicus, $M$. alba and A. pedunculata have higher amounts of total iron content, the Asc content is low in these fruits. According to previous studies iron content of $M$. alba is ranged from 0.2 to $4.67 \mathrm{mg} / 100 \mathrm{gm}(31,32$, 40).

\section{Principal component analysis (PCA)}

In PCA, 2 principal components (PCs) have been extracted from the original data, according to the Kaiser's rule (eigenvalues $>1.0$ ). The Kaiser-MeyerOlkin measure of sampling adequacy is 0.792 . Loading values, eigenvalues and \% cumulative variance obtained for PCs are as in the Table 4 . The percent cumulative variance of first two principal components was almost $64 \%$ of the total variance. Loading values higher than 0.7 are marked in boldface type in Table 4 . The PC1 correlates highly with the original variables in descending order as ARP, TC, mean Asc and TF. These variables positively loaded heavily on the PC1, as worked out on the guideline provided by Pituch and Stevens (factor loading > 0.72) (49). These variables are highly correlated. However, DAsc, FRAP, TF and Fe did not match the Steven's guideline.

The score plot resulted from PCA is illustrated in the Fig. 1. In the plot 4 separated clusters can be seen those are separated by PC2. Majority of fruits are along the zero of the PC2 and in the negative side of PC1. Only 6 fruits are in the positive side of PC1 and these fruits have been extracted from other fruits due to high contents of studied health prompting factors. M. malabathricum is the best fruit among studied fruits which has the highest PC1 value. Secondly best fruit is $A$. willisii followed by $C$. hirta and $M$. calabura. The results of this study emphasize that the locally available MFs are rich in nutritional and health factors compared to most of the CFs.

Table 4. Loading values, eigenvalues and percent cumulative variance obtained for the 2 PCs.

\begin{tabular}{lll}
\hline Variable & PC1 & PC2 \\
\hline TC & 0.896 & -0.264 \\
\hline Mean Asc & 0.851 & 0.054 \\
\hline DAsc & 0.395 & -0.822 \\
\hline TP & 0.638 & 0.421 \\
\hline TF & 0.773 & 0.399 \\
\hline ARP & 0.913 & -0.056 \\
\hline FRAP & 0.653 & 0.066 \\
\hline Fe & -0.265 & 0.206 \\
\hline \% Cumulative & 4.019 & 1.134 \\
\hline PC Principal compone & 50.235 & 64.408
\end{tabular}

PC - Principal components; TC - total vitamin C; Asc - ascorbic acid; TP - total phenolic content; TF - total flavonoid content; ARP antiradical power; FRAP - ferric reducing antioxidant power. 


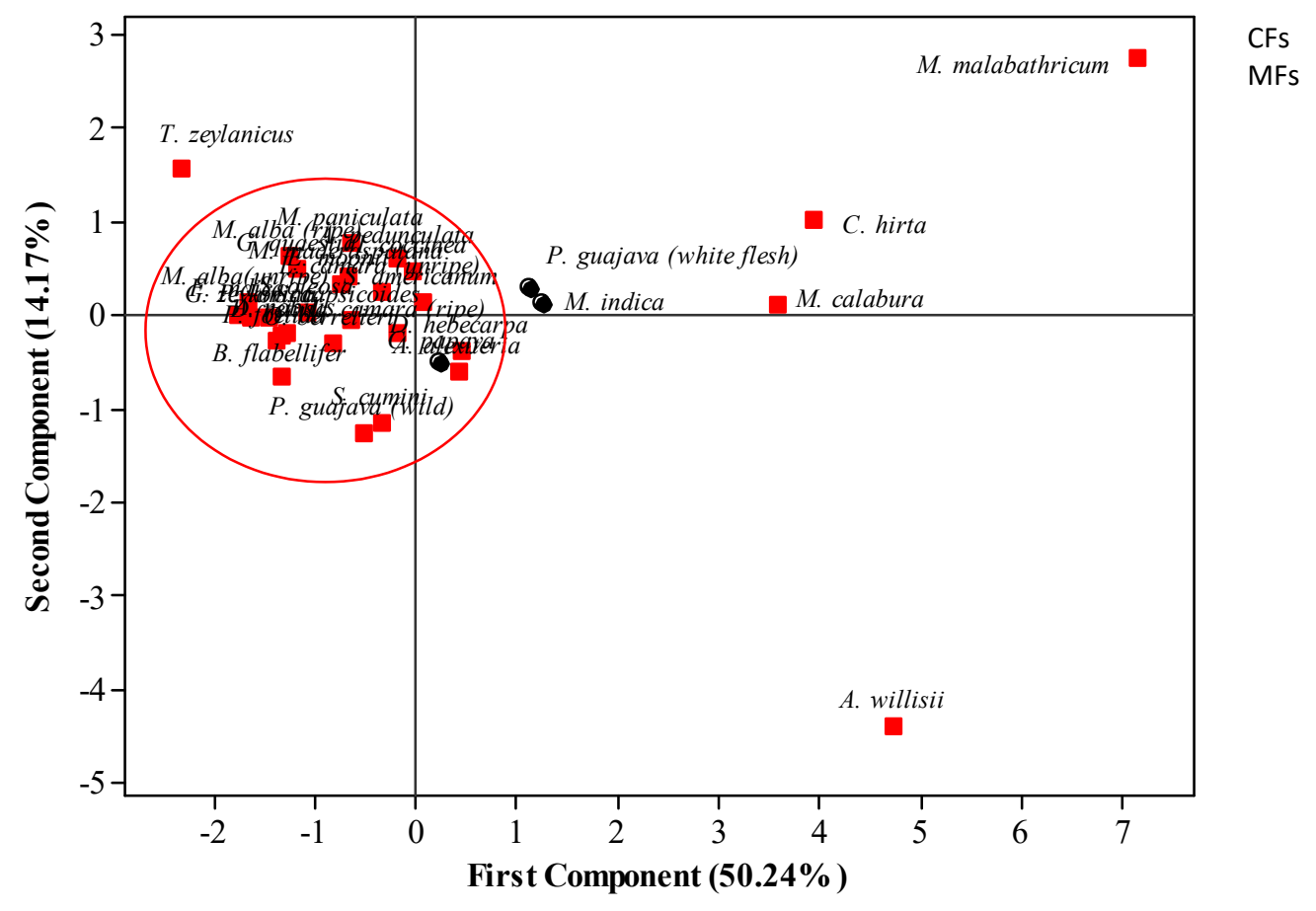

Fig. 1. Score plot for principal component analysis.

\section{Conclusion}

The results of the study revealed that minor fruits are rich in nutritional and health factors compared to common fruits in Sri Lanka. M. malabathricum is the fruit with the highest TP, TF and AOCs. The highest $\mathrm{TC}$ and DAsc are in A. willisii and the highest Asc content is found in M. calabura. T. zeylanicus has remarkably higher iron content. The results of this study reveal the importance of paying attention for utilization, cultivation, value addition and creating proper marketing channels to promote consumption of minor fruits among Sri Lankans as an alternative to common fruits.

\section{Acknowledgements}

Authors acknowledge UGC Block Grant [RU/PG-R/16/13] for financial support.

\section{Authors' contributions}

All authors collaborated in the development of research, experimental designing, writing and editing the manuscript.

\section{Conflict of interests}

The authors declare that they have no competing interests regarding the publication of this paper.

\section{References}

1. Ashton MS, Gunatilleke S, Zoysa ND, Dassanayake M, Gunatilleke N, Wijesundera S. A Field Guide to the Common
Trees and Shrubs of Sri Lanka. Sri Lanka: WHT Publications (Pvt.) Limited; 1997.

2. Bandula A, Jayaweera C, Silva AD, Oreiley $P$, Karunarathne A, Malkanthi SHP. Role of underutilized crop value chains in rural food and income security in Sri Lanka. Procedia Food Sci. 2016;6:267-70. http://doi.org/10.1016/j.profoo.2016.02.049

3. Malkanthi SHP, Karunaratne AS, Amuwala SD, Silva P. Opportunities and challenges in cultivating underutilized field crops in Moneragala district of Sri Lanka. Asian Journal of Agriculture and Rural Development. 2014;4(1):96-105. http://doi.org/10.4038/tar.v30i3.8315

4. Weerahewa J, Rajapakse C, Pushpakumara G. An analysis of consumer demand for fruits in Sri Lanka. Appetite. 2013;60(1):252-58. https://doi.org/10.1016/j.appet.2012.09.017

5. Mayes S, Massawe FJ, Alderson PG. The potential for underutilized crops to improve security of food production. Journal of Experimental Botany, 2012;63(3):1075-79. https://doi.org/10.1093/jxb/err396

6. Pushpakumara DKNG, Heenkenda HMS, Marambe B, Ranil RHG, Punyawardena BVR, Weerahewa J et al. Kandyan home gardens: a time-tested good practice from Sri Lanka for conserving tropical fruit tree diversity. In: Tropical fruit tree diversity: good practice for in-situ and on-farm conservation. Abingdon, Oxon: Routlendge; 2016:127-46.

7. Senaratna LK. A check list of the flowering plants of Sri Lanka. Sri Lanka: National Science Foundation; 2001.

8. Yasapalitha TA, Rupasinghe RS. Sri Lankave Wana Palthuru. Sri Lanka: Wasana Publishers; 2016.

9. Piyathunga A, Mallawaarachchi M, Madhujith W. Phenolic content and antioxidant capacity of selected underutilized fruits grown in Sri Lanka. Trop Agric Res. 2016;27(3):27786.

10. Bopitiya D, Madhujith T. Antioxidant potential of pomegranate (Punica granatum L.) cultivars. Trop Agric Res. 2012;24(1):71-81.

11. Hewage S., Premakumara G., Madhujith T. Study on antioxidant activity of mangosteen (Garcinia mangostana). Paper presented at: $64^{\text {th }}$ Annual Sessions, Sri 
Lanka Association for the Advancement of Science; Sri Lanka; 2008 Dec 1-6.

12. Mallawaarachchi MALN, Madhujith WMT, Pushpakumara DKNG. Antioxidant potential of selected underutilized fruit crop species grown in Sri Lanka. Trop Agric Res. 2019;30(3):1-12. http://doi.org/10.4038/tar.v30i3.8315

13. Manuha $M$, Iqbal $N$, Nageeb $B$, Paranagama $P$ Determination of vitamin $\mathrm{C}$ (ascorbic acid) in lime and lemon. Paper presented at: 2nd International Conference on Ayurveda, Unani, Siddha and Traditional Medicine (iCAUST); Sri Lanka; 2014 Dec 16-18.

14. Nadeesha M, Bamunuarachchi A, Edirisinghe E, Weerasinghe W. Studies on antioxidant activity of Indian gooseberry fruit and seed. Journal of Science of the University of Kelaniya, Sri Lanka. 2007;3:83-92.

15. Padmini S, Samarasekera R, Pushpakumara D Antioxidant capacity and total phenol content of Sri Lankan Annona muricata L. Trop Agric Res. 2014;25(2):252-60. http://doi.org/10.4038/tar.v25i2.8146

16. Sarananda KH, Thillakawardane TU, Alexander B Production of health-friendly, ready-to-serve fruit drinks from under-utilized local fruits from Sri Lanka. Sri Lanka Journal of Food and Agriculture. 2017;3(2):37-48 http://doi.org/10.4038/sljfa.v3i2.50

17. Sirasa MSF, Rukiya MJF, Silva KDRR. Antioxidant properties of selected commonly consumed and underutilized fruits in Sri Lanka. Paper presented at: Peradeniya Univ. International Research Sessions; Sri Lanka; 2014 Jul 4-5.

18. Silva KDRR, Sirasa MSF. Antioxidant properties of selected fruit cultivars grown in Sri Lanka. Food Chem. 2018;238:203-08.

https://doi.org/10.1016/j.foodchem.2016.08.102

19. Abeysuriya HI, Bulugahapitiya VP, Jayatissa LP. Total vitamin C, ascorbic acid, dehydroascorbic acid, antioxidant properties and iron content of underutilized and commonly consumed fruits in Sri Lanka. Int J Food Sci [Internet]. 2020 [cited 2021 Apr 12] https://www.hindawi.com/journals/ijfs/2020/4783029/

20. Nielsen SS. Food Analysis. $4^{\text {th }}$ ed. New York, USA: Springer Science and Business Media, Inc.; 2010:55-60.

21. Ikram EHK, Eng KH, Jalil AMM, Ismail A, Idris S, Azlan A et al. Antioxidant capacity and total phenolic content of Malaysian underutilized fruits. J Food Compost Anal. 2009;22:388-93. https://doi.org/10.1016/j.jfca.2009.04.001

22. Ranganna S. Hand book of analysis and quality control for fruit and vegetable products. New Delhi, India: Tata McGraw-Hill Publishing Company Limited; 1999.

23. Suntornsuk L, Gritsanapun W, Nilkamhank S, Paochom A. Quantitation of vitamin C content in herbal juice using direct titration. J Pharm Biomed. 2002;28(5):849-55. https://doi.org/10.1016/S0731-7085(01)00661-6

24. Lim YY, Lim TT, Tee JJ. Antioxidant properties of several tropical fruits: A comparative study. Food Chem. 2007;103(3):1003-08.

https://doi.org/10.1016/j.foodchem.2006.08.038

25. Yadav RNS, Agarwala M. Phytochemical analysis of some medicinal plants. J Phytol. 2011;3(12):10-14

26. Brand-Williams W, Cuvelier M, Berset C. Use of free radical method to evaluate antioxidant activity. LWT-Food Sci Technol. 1995;28(1):25-30. https://doi.org/10.1016/S0023-6438(95)80008-5

27. Benzie IF, Strain J. Ferric reducing/ antioxidant power assay: Direct measure of total antioxidant activity of biological fluids and modified version for simultaneous measurement of total antioxidant power and ascorbic acid concentration. Meth Enzymol. 1999;299:15-27. https://doi.org/10.1016/s0076-6879(99)99005-5

28. Jorhem L. Determination of metals in foods by atomic absorption spectrometry after dry ashing: NMKL1 collaborative study. J AOAC Int. 2000;83(5):1204-11.
29. Fenech M, Amaya I, Valpuesta V, Botella MA. Vitamin C content in fruits: biosynthesis and regulation. Front Plant Sci [Internet]. 2019 [cited 2021 Apr 1];9:1-21. https://www.frontiersin.org/articles/10.3389/fpls.2018.020 06/full.

30. Banoo A, Dolkar T, Ali M. Role of physical and chemical performance during storage of apple cultivar. J Pharmacogn Phytochem. 2018;7(2):1332-38. http://www.phytojournal.com/archives/2018/vol7issue2/Pa rtS/7-2-26-148.pdf

31. Ercisli S, Orhan E. Chemical composition of white (Morus alba), red (Morus rubra) and black (Morus nigra) mulberry fruits. Food Chem. 2007;103(4):1380-84 https://doi.org/10.1016/j.foodchem.2006.10.054

32. Gungor N, Sengul M. Antioxidant activity, total phenolic content and selected physiochemical properties of white mulberry (Morus alba L.) fruits. Int J Food Prop. 2008;11:44-52. https://doi.org/10.1080/10942910701558652

33. Guofang X, Xiaoyan X, Xiaoli Z, Yongling L, Zhibing Z Changes in phenolic profiles and antioxidant activity in rabbiteye blueberries during ripening. Int J Food Prop. 2019;22(1):320-29.

https://doi.org/10.1080/10942912.2019.1580718

34. Anton D, Bender I, Kaart T, Roasto M, Heinonen M, Luik A et al. Changes in polyphenols contents and antioxidant capacities of organically and conventionally cultivated tomato (Solanum lycopersicum L.) fruits during ripening. Int J Anal Chem [Internet]. 2017 [cited 2021 Feb 28]. https://www.hindawi.com/journals/ijac/2017/2367453/

35. Bashir HA, Abu-Goukh AA. Compositional changes during guava fruit ripening. Food Chem. 2003;80(4):557-63. https://doi.org/10.1016/S0308-8146(02)00345-X

36. Ibrahim KE, Abu-Goukh AA, Yusuf KS. Use of ethylene, acetylene and ethrel on banana fruit ripening. University of Khartoum Journal of Agricultural Sciences. 1994;2(1):73-92.

37. Abu-Goukh AA, Abu-Sarra AF. Compositional changes during mango fruit ripening. University of Khartoum Journal of Agricultural Sciences. 1993;1(1):33-51. https://doi.org/10.1111/j.1365-2621.1985.tb10555.x.

38. Arena E, Fallico B, Maccarone E. Evaluation of antioxidant capacity of blood orange juices as influenced by constituents, concentration process and storage. Food Chemistry. http://dx.doi.org/10.1016/S0308-8146(01)00125-X

39. Narayana SD, Wedamulla NE, Wijesinghe WA, Rajakaruna RA. Extraction of anthocyanin from Hinembilla (Antidesma alexiteria) fruit as a natural food colorant. Paper presented at: International Research Conference of Uva Wellassa University; International Research Conference of Uva Wellassa University; Sri Lanka; 2019 Feb 08.

40. Sánchez-Salcedo EM, Mena P, García-Viguera C, Martínez JJ, Hernández F. Phytochemical evaluation of white (Morus alba L.) and black (Morus nigra L.) mulberry fruits, a starting point for the assessment of their beneficial properties. J Funct Foods. 2015;12:399-408. https://doi.org/10.1016/j.jff.2014.12.010

41. Kubola J, Siriamornpun S, Meeso N. Phytochemicals vitamin $C$ and sugar content of Thai wild fruits. Food Chem. 2011:126(3):972-81. https://doi.org/10.1016/j.foodchem.2010.11.104

42. Rufino MSM, Alves RE, Brito ES, Pérez-Jiménez J, SauraCalixto F, Mancini-Filho J. Bioactive compounds and antioxidant capacities of 18 non-traditional tropical. Food Chem. 2010;121(4):996-1002. https://doi.org/10.1016/j.foodchem.2010.01.037

43. Lim TK. Edible medicinal and non-medicinal plants: Fruits (Vol. I). New York, USA: Springer; 2012

44. Bochi VC, Barcia MT, Rodrigues D, Speroni CS, Giusti MM, Godoy HT. Polyphenol extraction optimisation from Ceylon gooseberry (Dovyalis hebecarpa) pulp. Food Chem. 2014;164(1):347-54.

https://doi.org/10.1016/j.foodchem.2014.05.031 
45. Bochi VC, Barcia MT, Rodrigues D, Godoy HT. Biochemical characterization of Dovyalis hebecarpa fruits: A source of anthocyanins with high antioxidant capacity. J Food Sci. 2015;80(10):127-33. $\quad$ https://doi.org/10.1111/1750 3841.12978

46. Rotili MC, Villa F, Braga GC, França DL, Rosanelli S, Laureth JC, da Silva DF. Bioactive compounds, antioxidant and physic-chemical characteristics of the dovyalis fruit. Acta Sci Agron. https://doi.org/10.4025/actasciagron.v40i2.35465

47. Huang W, Cai Y, Corke H, Sun M. Survey of antioxidant capacity and nutritional quality of selected edible and medicinal fruit plants in Hong Kong. J Food Compost Anal. 2010;23(6):510-17.

https://doi.org/10.1016/j.jfca.2009.12.006

48. Zimmermann MB, Hurrell RF. Nutritional iron deficiency. Lancet. 2007;370:511-20. https://doi.org/10.1016/s0140 6736(07)61235-5

49. Pituch KA, Stevens JP. Applied Multivariate Statistics for the Social Sciences. New York: Routledge; 2016.
Additional information

Peer review information: Plant Science Today thanks Sectional Editor and the other anonymous reviewers for their contribution to the peer review of this work.

Reprints and permissions information is available at https://horizonepublishing.com/journals/index.php/PST/open_access_policy

Publisher's Note: Horizon e-Publishing Group remains neutral with regard to jurisdictional claims in published maps and institutional affiliations.

To cite this article: Abeysuriya H I, Bulugahapitiya V P, Jayatissa L P. Comparative account of vitamin $\mathrm{C}$ contents, antioxidant properties and iron contents of minor fruits in Sri Lanka. Plant Science Today. 2021;8(4):795-803. https://doi.org/10.14719/pst.2021.8.4.1266

Plant Science Today, published by Horizon e-Publishing Group, is covered by Scopus, Web of Science, BIOSIS Previews, Clarivate Analytics, etc. See https://horizonepublishing.com/journals/index.php/PST/indexing_abstracting 